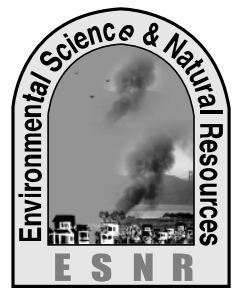

J. Environ. Sci. \& Natural Resources, 6(1) : 07 - 10, 2013

ISSN 1999-7361

\title{
Feasibility of Replacing Chemical Fertilizer by Using Organic Fertilizer in Wheat (Triticum aestivum) Considering Dry Matter Content and Estimatimation of Different Growth Parameters
}

\author{
Z. Akhter ${ }^{1}$, M. H. Imam ${ }^{2}$, M. A. Razzak ${ }^{1}$, A. H. M. M. R. AKhter ${ }^{3}$ and M. AKhter ${ }^{4}$ \\ ${ }^{1}$ Department of Agronomy, Sher-E-Bangla Agricultural University \\ ${ }^{2}$ Election Commission Secretariat, Dhaka \\ ${ }^{3}$ Agronomy Division, RARS, Jamalpur \\ ${ }^{4}$ SRDI, District Office, Jamalpur.
}

\begin{abstract}
An experiment was conducted at the experimental field of Sher-e-Bangla Agricultural University, Dhaka during the period from October 2010 to March 2011 to study the feasibility of replacing chemical fertilizer by using organic fertilizer in wheat. The experiment comprised of 10 treatments, such as $\mathrm{T}_{0}$ : Control condition; $\mathrm{T}_{1}$ : All chemical fertilizer as recommended dose; $\mathrm{T}_{2}$ : Cowdung as recommended dose; $\mathrm{T}_{3}$ : Compost as recommended dose; $\mathrm{T}_{4}: 1 / 2$ Cowdung $+1 / 2$ Compost; $\mathrm{T}_{5}$ : Cowdung + Compost; $\mathrm{T}_{6}$ : Cowdung $+1 / 2$ Chemical fertilizer; $\mathrm{T}_{7}$ : Compost $+1 / 2$ Chemical fertilizer; $\mathrm{T}_{8}$ : Cowdung + Compost $+1 / 2$ Chemical fertilizer and $\mathrm{T}_{9}: 1 / 2$ Cowdung $+1 / 2$ Compost $+1 / 2$ Chemical fertilizer. The experiment was laid out in Randomized Complete Block Design (RCBD) with three replications. At 30, 50, 70, 90 and 110 (Days After Sowing) DAS, the highest dry matter content plant ${ }^{-}$ ${ }^{1}$ was recorded from $\mathrm{T}_{1}(0.30 \mathrm{~g}, 3.87 \mathrm{~g}, 8.84 \mathrm{~g}, 19.58 \mathrm{~g}$ and $30.18 \mathrm{~g})$, whereas the lowest weight from $\mathrm{T}_{0}(0.18 \mathrm{~g}, 2.49 \mathrm{~g}, 6.50 \mathrm{~g}$, $11.80 \mathrm{~g}$ and $18.08 \mathrm{~g}$ ). At 30-50 DAS, the highest (Crop Growth Rate) CGR was found from $\mathrm{T}_{1}\left(5.35 \mathrm{~g} \mathrm{~m}^{-2} \mathrm{day}^{-1}\right)$, while the lowest CGR from $\mathrm{T}_{0}\left(3.46 \mathrm{~g} \mathrm{~m}^{-2} \mathrm{day}^{-1}\right)$. At 50-70 DAS, the highest CGR was found from $\mathrm{T}_{7}\left(8.34 \mathrm{~g} \mathrm{~m}^{-2} \mathrm{day}^{-1}\right)$, while the lowest CGR from $\mathrm{T}_{0}\left(6.70 \mathrm{~g} \mathrm{~m}^{-2} \mathrm{day}^{-1}\right)$. At 70-90 DAS, the highest CGR was found from $\mathrm{T}_{1}\left(17.89 \mathrm{~g} \mathrm{~m}^{-2}\right.$ day $\left.^{-1}\right)$, while the lowest CGR from $\mathrm{T}_{0}(8.83 \mathrm{~g}$ $\mathrm{m}^{-2}$ day $\left.^{-1}\right)$. At 90-110 DAS, the highest CGR was found from $\mathrm{T}_{8}\left(18.69 \mathrm{~g} \mathrm{~m}^{-2} \mathrm{day}^{-1}\right)$, while the lowest CGR from $\mathrm{T}_{0}\left(10.47 \mathrm{~g} \mathrm{~m}^{-}\right.$ $\left.{ }^{2} \mathrm{day}^{-1}\right)$. At 30-50 DAS, the highest RGR was found from $\mathrm{T}_{3}\left(0.134 \mathrm{~g} \mathrm{~g}^{-1} \mathrm{day}^{-1}\right)$ and the lowest RGR from $\mathrm{T}_{5}$ and $\mathrm{T}_{8}\left(0.127 \mathrm{~g} \mathrm{~g}^{-1}\right.$ day $\left.^{-1}\right)$. At 50-70 DAS, the highest RGR was found from $\mathrm{T}_{3}\left(0.049 \mathrm{~g} \mathrm{~g}^{-1} \mathrm{day}^{-1}\right)$ and the lowest RGR from T $9\left(0.041 \mathrm{~g} \mathrm{~g}^{-1} \mathrm{day}^{-1}\right)$. At 70-90 DAS, the highest RGR was found from $\mathrm{T}_{3}\left(0.040 \mathrm{~g} \mathrm{~g}^{-1}\right.$ day $\left.^{-1}\right)$ and the lowest RGR from $\mathrm{T}_{0}\left(0.030 \mathrm{~g} \mathrm{~g}^{-1} \mathrm{day}^{-1}\right)$. At 90-110 DAS, the highest (Relative Growth Rate) RGR was found from $\mathrm{T}_{3}\left(0.026 \mathrm{~g} \mathrm{~g}^{-1}\right.$ day $\left.^{-1}\right)$ and the lowest RGR from T $0.021 \mathrm{~g} \mathrm{~g}^{-1}$ day $\left.^{-1}\right)$. The longest spike $(19.86 \mathrm{~cm})$, highest grain yield $\left(3.71 \mathrm{t} \mathrm{ha}^{-1}\right)$ and highest straw yield $\left(5.78 \mathrm{t} \mathrm{ha}^{-1}\right)$ was attained from $\mathrm{T}_{1}$ and the shortest spike $(14.33 \mathrm{~cm})$, lowest grain yield $\left(2.06 \mathrm{t} \mathrm{ha}^{-1}\right)$ and lowest straw yield $\left(4.49 \mathrm{t} \mathrm{ha}^{-1}\right)$ from $\mathrm{T}_{0}$.
\end{abstract}

Key words: Wheat, chemical fertilizer, Organic fertilizer, Dry matter and growth parameter.

\section{Introduction}

Wheat (Triticum aestivum L.) is one of the most important cereal crops and it is as well as a staple food and shaws the large acreage among all the field crops in the world (FAO, 2010). About two third of the total world's population consume wheat as staple food (Majumder, 1991). The crop is grown under different environmental condition ranging from humid to arid, subtropical to temperate zone. Dubin and Ginkel (1991) reported that the largest area of wheat cultivation in the warmer climates exists in the South-East Asia including Bangladesh, India and Nepal. Wheat is the second most important cereal crops in Bangladesh that contribute to the national economy by reducing the volume of import of cereals for fulfilling our this food requirements of the country (Razzaque et al., 1992). Wheat grain is rich in food value containing $69.60 \%$ carbohydrate, $12.00 \%$ protein, $1.72 \%$ fat $17.20 \%$ and minerals (BARI, 2006). Wheat cultivation has been increased manifolds to meet up the food shortage in the country. The area, production and yield of wheat have been increasing dramatically during the last two decades, but its present yield is too low in comparison to that of some developed countries like Japan, France, Germany and UK producing 3.76,
7.12, 7.28, and $8.00 \mathrm{t} \mathrm{ha}^{-1}$, respectively (FAO, 2000). In Bangladesh, the position of wheat is second in respect of total area (0.80 million hectares) and production (2.80 million ton) after rice and the average yield is only $3.44 \mathrm{t}$ $\mathrm{ha}^{-1}$ (BBS, 2010) but it can be increased up to $6.8 \mathrm{t} \mathrm{ha}^{-1}$ (RARS, 2010).To increase yield of wheat, care should be taken to improve crop growth rate as well as its relative growth rate crop growth and relative growth rate.

Application of both chemical and organic fertilizers is need for the improvement of soil physical properties and quick supply of essential plant nutrients for higher yield. The combined effect of organic manure and inorganic fertilizer on crop yield was also reported by many workers (Davarynejad et al., 2004; Singh and Singh, 2000). Therefore the present work was undertaken to study feasibility of replacing chemical fertilizer by using organic fertilizer in wheat (triticum aestivum) considering dry matter content, and estimatimation of different growth parameters. 


\section{Materials and Methods}

The experiment was conducted to study the feasibility of replacing chemical fertilizer by using organic fertilizer in wheat during the period from October 2010 to March 2011. The experiment comprised the 10 treatments i.e., $\mathrm{T}_{0}$ : Control (without manure and fertilizer); $\mathrm{T}_{1}$ : All chemical fertilizers as recommended dose; $\mathrm{T}_{2}$ : Cowdung as recommended dose; $\mathrm{T}_{3}$ : Compost as recommended dose; $\mathrm{T}_{4}: 1 / 2$ Cowdung $+1 / 2$ Compost; $\mathrm{T}_{5}$ : Cowdung + Compost; $\mathrm{T}_{6}$ : Cowdung $+1 / 2$ Chemical fertilizer; $\mathrm{T}_{7}$ : Compost $+1 / 2$ Chemical fertilizer; $\mathrm{T}_{8}$ : Cowdung + Compost $+1 / 2$ Chemical fertilizer and $T_{9}: 1 / 2$ Cowdung + $1 / 2$ Compost $+1 / 2$ Chemical fertilizer. Recommended dose of chemical fertilizer, cowdung and compost for this experiment were Urea: $220 \mathrm{~kg} \mathrm{ha}^{-1}$, TSP: $180 \mathrm{~kg} \mathrm{ha}^{-1}$, MP: $50 \mathrm{~kg} \mathrm{ha}^{-1}$, Gypsum: $120 \mathrm{~kg} \mathrm{ha}^{-1}$, Zinc oxide: $5 \mathrm{~kg}$ ha ${ }^{-1}$, Boric acid: $6 \mathrm{~kg} \mathrm{ha}^{-1}$, Cowdung: 8 ton $\mathrm{ha}^{-1}$ and compost: 8 ton ha $^{-1}$. CGR and RGR were calculated using formulas as described by Hunt (1971).

$\mathrm{CGR}=$

$$
\frac{\mathrm{InW}_{2}-\mathrm{In} \mathrm{W}_{1}}{\mathrm{~T}_{2}-\mathrm{T} \mathrm{m}_{1}} \mathrm{day}^{-1}
$$

CGR is the dry matter production per unit of time per ground area.

$\mathrm{RGR}=$

$$
\frac{\mathrm{DM}_{2}-\mathrm{DM}_{1}}{\mathrm{~T}_{2}-\mathrm{T}_{1}} \mathrm{gg}^{-1} \text { day }^{-1}
$$

RGR is the dry matter production per unit of time per plant.

The data obtained for different characters were statistically analyzed to observe the significant difference among the treatment. The mean values of all the characters were calculated and analyses of variance were performed. The significance of the difference among the treatment means was estimated by the
Duncan Multiple Range Test (DMRT) at 5\% level of probability (Gomez and Gomez, 1984).

\section{Results and Discussion}

Different chemical and organic fertilizers and their combinations showed significant variation for dry matter content plant ${ }^{-1}$ at 30, 50, 70, 90 and 110 DAS (Table 1). At 30 DAS, the highest dry matter content plant ${ }^{-1}$ was recorded from $\mathrm{T}_{1}(0.30 \mathrm{~g})$, which was statistically similar with $\mathrm{T}_{8}, \mathrm{~T}_{9}, \mathrm{~T}_{5}$ and $\mathrm{T}_{7}(0.29 \mathrm{~g}, 0.28 \mathrm{~g}, 0.25 \mathrm{~g}$ and $0.25 \mathrm{~g}$, respectively) and closely followed by $\mathrm{T}_{6}(0.24 \mathrm{~g})$, whereas the lowest from $\mathrm{T}_{0}(0.18 \mathrm{~g})$, which was statistically similar with $\mathrm{T}_{2}, \mathrm{~T}_{3}$, and $\mathrm{T}_{4}(0.20 \mathrm{~g}, 0.20 \mathrm{~g}$ and $0.22 \mathrm{~g}$, respectively). At $50 \mathrm{DAS}$, the highest dry matter content plant ${ }^{-1}$ was observed from $\mathrm{T}_{1}(3.87 \mathrm{~g})$, which was statistically similar with $\mathrm{T}_{8}$ and $\mathrm{T}_{9}(3.71 \mathrm{~g}$ and $3.67 \mathrm{~g}$, respectively) and followed by $\mathrm{T}_{7}(3.30 \mathrm{~g})$, whereas the lowest from $\mathrm{T}_{0}(2.49 \mathrm{~g})$. At 70 DAS, the highest dry matter content plant ${ }^{-1}$ was obtained from $T_{1}$ $(8.84 \mathrm{~g})$, which was statistically identical with $\mathrm{T}_{8}, \mathrm{~T}_{9}, \mathrm{~T}_{7}$, $\mathrm{T}_{6}$ and $\mathrm{T}_{3}(8.71 \mathrm{~g}, 8.37 \mathrm{~g}, 8.30 \mathrm{~g}, 8.11 \mathrm{~g}$ and $7.95 \mathrm{~g}$, respectively), while the lowest from $\mathrm{T}_{0}(6.50 \mathrm{~g})$. At 90 DAS, the highest dry matter content plant ${ }^{-1}$ was recorded from $T_{1}(19.58 \mathrm{~g})$, which was statistically similar with $\mathrm{T}_{8}$ $(17.90 \mathrm{~g})$ and closely followed by $\mathrm{T}_{7}, \mathrm{~T}_{6}$ and $\mathrm{T}_{5}(17.03 \mathrm{~g}$, $16.38 \mathrm{~g}$ and $16.07 \mathrm{~g}$, respectively) and that of lowest from $\mathrm{T}_{0}(11.80 \mathrm{~g})$. At harvest, the highest dry matter content plant ${ }^{-1}$ was attained in $T_{1}(30.18 \mathrm{~g})$, which was statistically similar with $\mathrm{T}_{8}, \mathrm{~T}_{9}$ and $\mathrm{T}_{7}(29.11 \mathrm{~g}, 28.01 \mathrm{~g}$ and $27.61 \mathrm{~g}$, respectively) and closely followed by $\mathrm{T}_{6}$ and $\mathrm{T}_{5}$ (26.82 $\mathrm{g}$ and $26.74 \mathrm{~g}$, respectively), again the lowest $\mathrm{T}_{0}(18.08 \mathrm{~g})$. Application of all chemical fertilizer in recommended doses gave the highest dry matter accumulation followed by the combination of cowdung, compost and chemical fertilizers half in recommended doses.

Table 1. Effect of chemical and organic fertilizers and their combinations on dry matter plant ${ }^{-1}$ of wheat

\begin{tabular}{rlllll}
\hline Treatment & \multicolumn{5}{c}{ Dry matter plant $^{-1}(\mathrm{~g})$ at } \\
\cline { 2 - 6 } & $30 \mathrm{DAS}$ & $50 \mathrm{DAS}$ & $70 \mathrm{DAS}$ & $90 \mathrm{DAS}$ & $110 \mathrm{DAS}$ \\
\hline $\mathrm{T}_{0}$ & $0.18 \mathrm{~d}$ & $2.49 \mathrm{~d}$ & $6.50 \mathrm{~d}$ & $11.80 \mathrm{e}$ & $18.08 \mathrm{~d}$ \\
$\mathrm{~T}_{1}$ & $0.30 \mathrm{a}$ & $3.87 \mathrm{a}$ & $8.84 \mathrm{a}$ & $19.58 \mathrm{a}$ & $30.18 \mathrm{a}$ \\
$\mathrm{T}_{2}$ & $0.20 \mathrm{~cd}$ & $2.91 \mathrm{c}$ & $7.53 \mathrm{c}$ & $15.34 \mathrm{~d}$ & $25.67 \mathrm{c}$ \\
$\mathrm{T}_{3}$ & $0.20 \mathrm{~cd}$ & $2.98 \mathrm{c}$ & $7.95 \mathrm{a}-\mathrm{c}$ & $15.47 \mathrm{~d}$ & $25.86 \mathrm{c}$ \\
$\mathrm{T}_{4}$ & $0.22 \mathrm{~cd}$ & $3.05 \mathrm{c}$ & $7.86 \mathrm{bc}$ & $15.82 \mathrm{~cd}$ & $25.99 \mathrm{c}$ \\
$\mathrm{T}_{5}$ & $0.25 \mathrm{a}-\mathrm{c}$ & $3.15 \mathrm{c}$ & $7.76 \mathrm{bc}$ & $16.07 \mathrm{~b}-\mathrm{d}$ & $26.74 \mathrm{bc}$ \\
$\mathrm{T}_{6}$ & $0.24 \mathrm{~b}-\mathrm{d}$ & $3.17 \mathrm{c}$ & $8.11 \mathrm{a}-\mathrm{c}$ & $16.38 \mathrm{~b}-\mathrm{d}$ & $26.82 \mathrm{bc}$ \\
$\mathrm{T}_{7}$ & $0.25 \mathrm{a}-\mathrm{c}$ & $3.30 \mathrm{bc}$ & $8.30 \mathrm{a}-\mathrm{c}$ & $17.03 \mathrm{~b}-\mathrm{d}$ & $27.61 \mathrm{a}-\mathrm{c}$ \\
$\mathrm{T}_{8}$ & $0.29 \mathrm{ab}$ & $3.71 \mathrm{a}$ & $8.71 \mathrm{ab}$ & $17.90 \mathrm{ab}$ & $29.11 \mathrm{ab}$ \\
$\mathrm{T}_{9}$ & $0.28 \mathrm{ab}$ & $3.67 \mathrm{ab}$ & $8.37 \mathrm{a}-\mathrm{c}$ & $17.62 \mathrm{bc}$ & $28.01 \mathrm{a}-\mathrm{c}$ \\
\hline $\mathrm{SE}$ & 0.018 & 0.132 & 0.291 & 0.616 & 0.885 \\
\hline $\mathrm{CV}(\%)$ & 10.24 & 7.06 & 6.30 & 6.55 & 5.80 \\
\hline
\end{tabular}

In a column, means having similar letter(s) are statistically similar and those having dissimilar letter(s) differ significantly as per 0.05 level of significance. $\mathrm{CV}=\mathrm{Co}$-efficient of variance. 
CGR varied significantly for different chemical and organic fertilizers and their combinations at 30-50, 50-70, 70-90 and 90-110 (Table 2). At 30-50 DAS, the highest CGR was found in $\mathrm{T}_{1}\left(5.35 \mathrm{~g} \mathrm{~m}^{-2} \mathrm{day}^{-1}\right)$, while the lowest CGR was recorded in $\mathrm{T}_{0}\left(3.46 \mathrm{~g} \mathrm{~m}^{-}\right.$ ${ }^{2}$ day $\left.^{-1}\right)$. At 50-70 DAS, the highest CGR was found in $\mathrm{T}_{7}\left(8.34 \mathrm{~g} \mathrm{~m}^{-2} \mathrm{day}^{-1}\right)$, while the lowest CGR was recorded in $\mathrm{T}_{0}\left(6.70 \mathrm{~g} \mathrm{~m}^{-2} \mathrm{day}^{-1}\right)$. At 70-90 DAS, the highest CGR was found in $\mathrm{T}_{1}\left(17.89 \mathrm{~g} \mathrm{~m}^{-2} \mathrm{day}^{-1}\right)$, while the lowest CGR was recorded in $\mathrm{T}_{0}\left(8.83 \mathrm{~g} \mathrm{~m}^{-2}\right.$ day $\left.^{-1}\right)$. At 90-110 DAS, the highest CGR was found in $\mathrm{T}_{8}\left(18.69 \mathrm{~g} \mathrm{~m}^{-2} \mathrm{day}^{-1}\right)$, while the lowest CGR was recorded in $\mathrm{T}_{0}\left(10.47 \mathrm{~g} \mathrm{~m}^{-2}\right.$ day $\left.^{-1}\right)$.

Table 2. Effect of chemical and organic fertilizers and their combinations on Crop Growth Rate (CGR) of wheat

\begin{tabular}{ccccc}
\hline Treatment & \multicolumn{4}{c}{ Crop Growth Rate $\left(\mathrm{g} \mathrm{m}^{-2} \mathrm{day}^{-1}\right)$ at } \\
\cline { 2 - 5 } & $30-50 \mathrm{DAS}$ & $50-70 \mathrm{DAS}$ & $70-90 \mathrm{DAS}$ & $90-110 \mathrm{DAS}$ \\
\hline $\mathrm{T}_{0}$ & $3.46 \mathrm{~d}$ & $6.70 \mathrm{~b}$ & $10.47 \mathrm{~b}$ \\
$\mathrm{~T}_{1}$ & $5.35 \mathrm{a}$ & $8.29 \mathrm{a}$ & $17.89 \mathrm{a}$ & $17.67 \mathrm{a}$ \\
$\mathrm{T}_{2}$ & $4.07 \mathrm{c}$ & $7.69 \mathrm{a}$ & $13.03 \mathrm{~b}$ & $17.21 \mathrm{a}$ \\
$\mathrm{T}_{3}$ & $4.17 \mathrm{c}$ & $8.28 \mathrm{a}$ & $12.53 \mathrm{~b}$ & $16.32 \mathrm{a}$ \\
$\mathrm{T}_{4}$ & $4.25 \mathrm{c}$ & $8.02 \mathrm{a}$ & $13.26 \mathrm{~b}$ & $17.94 \mathrm{a}$ \\
$\mathrm{T}_{5}$ & $4.35 \mathrm{c}$ & $7.70 \mathrm{a}$ & $13.84 \mathrm{~b}$ & $17.79 \mathrm{a}$ \\
& $\mathrm{T}_{6}$ & $4.39 \mathrm{c}$ & $13.78 \mathrm{~b}$ & $17.41 \mathrm{a}$ \\
& $\mathrm{T}_{7}$ & $4.56 \mathrm{bc}$ & $14.55 \mathrm{~b}$ & $17.63 \mathrm{a}$ \\
& $\mathrm{T}_{8}$ & $5.13 \mathrm{ab}$ & $15.32 \mathrm{ab}$ & $18.69 \mathrm{a}$ \\
& $\mathrm{T}_{9}$ & $5.09 \mathrm{ab}$ & $8.34 \mathrm{a}$ & $17.31 \mathrm{a}$ \\
\hline $\mathrm{SE}$ & 0.197 & $7.82 \mathrm{a}$ & 0.859 & 0.838 \\
\hline $\mathrm{CV}(\%)$ & 7.60 & 0.243 & 10.74 & 8.62 \\
\hline
\end{tabular}

In a column, means having similar letter(s) are statistically similar and those having dissimilar letter(s) differ significantly as per 0.05 level of significance. $\mathrm{CV}=\mathrm{Co}$-efficient of variance.

RGR showed significant variation for different chemical and organic fertilizers and their combinations at 30-50, 50-70, 70-90 and 90-110 (Table 3). At 30-50 DAS, the highest RGR was found in $\mathrm{T}_{3}\left(0.134 \mathrm{~g} \mathrm{~g}^{-1} \mathrm{day}^{-1}\right)$ and the lowest RGR was recorded in $\mathrm{T}_{5}$ and $\mathrm{T}_{8}\left(0.127 \mathrm{~g} \mathrm{~g}^{-1}\right.$ day $\left.^{-1}\right)$. At $50-70$ DAS, the highest RGR was found in $\mathrm{T}_{3}\left(0.049 \mathrm{~g} \mathrm{~g}^{-1}\right.$ day $\left.^{-1}\right)$ and the lowest RGR was recorded in $\mathrm{T}_{9}(0.041$ $\mathrm{g} \mathrm{g}^{-1}$ day $\left.^{-1}\right)$. At 70-90 DAS, the highest RGR was found in $\mathrm{T}_{3}\left(0.040 \mathrm{~g} \mathrm{~g}^{-1} \mathrm{day}^{-1}\right)$ and the lowest RGR was recorded in $\mathrm{T}_{0}\left(0.030 \mathrm{~g} \mathrm{~g}^{-1} \mathrm{day}^{-1}\right)$. At $90-110$ DAS, the highest RGR was found in $\mathrm{T}_{3}\left(0.026 \mathrm{~g} \mathrm{~g}^{-1}\right.$ day $\left.^{-1}\right)$ and the lowest RGR was recorded in $\mathrm{T}_{0}(0.021$ $\mathrm{g} \mathrm{g}^{-1}$ day $\left.^{-1}\right)$.

Table 3. Effect of chemical and organic fertilizers and their combinations on Relative Growth Rate (RGR) of wheat

\begin{tabular}{|c|c|c|c|c|}
\hline \multirow[t]{2}{*}{ Treatment } & \multicolumn{4}{|c|}{ Relative growth rate $\left(\mathrm{g} \mathrm{g}^{-1}\right.$ day $\left.^{-1}\right)$ at } \\
\hline & $30-50 \mathrm{DAS}$ & 50-70 DAS & 70-90 DAS & 90-110 DAS \\
\hline $\mathrm{T}_{0}$ & $0.131 \mathrm{ab}$ & $0.048 \mathrm{ab}$ & $0.030 \mathrm{c}$ & $0.021 \mathrm{e}$ \\
\hline $\mathrm{T}_{1}$ & $0.128 \mathrm{ab}$ & $0.042 \mathrm{~cd}$ & $0.040 \mathrm{a}$ & $0.022 \mathrm{de}$ \\
\hline $\mathrm{T}_{2}$ & $0.133 \mathrm{a}$ & $0.047 \mathrm{a}-\mathrm{c}$ & $0.036 \mathrm{ab}$ & $0.026 \mathrm{a}$ \\
\hline $\mathrm{T}_{3}$ & $0.134 \mathrm{a}$ & $0.049 \mathrm{a}$ & $0.033 \mathrm{bc}$ & $0.025 \mathrm{ab}$ \\
\hline $\mathrm{T}_{4}$ & $0.132 \mathrm{ab}$ & $0.047 \mathrm{a}-\mathrm{c}$ & $0.035 \mathrm{a}-\mathrm{c}$ & $0.025 \mathrm{a}-\mathrm{c}$ \\
\hline $\mathrm{T}_{5}$ & $0.127 \mathrm{~b}$ & $0.045 \mathrm{a}-\mathrm{d}$ & $0.036 \mathrm{ab}$ & $0.025 \mathrm{ab}$ \\
\hline $\mathrm{T}_{6}$ & $0.130 \mathrm{ab}$ & $0.047 \mathrm{a}-\mathrm{d}$ & $0.035 \mathrm{a}-\mathrm{c}$ & $0.025 \mathrm{a}-\mathrm{c}$ \\
\hline $\mathrm{T}_{7}$ & $0.128 \mathrm{ab}$ & $0.046 \mathrm{a}-\mathrm{d}$ & $0.036 \mathrm{ab}$ & $0.024 b c$ \\
\hline $\mathrm{T}_{8}$ & $0.127 \mathrm{~b}$ & $0.043 \mathrm{~b}-\mathrm{d}$ & $0.036 \mathrm{ab}$ & $0.024 \mathrm{a}-\mathrm{c}$ \\
\hline $\mathrm{T}_{9}$ & $0.129 \mathrm{ab}$ & $0.041 \mathrm{~d}$ & $0.037 \mathrm{ab}$ & $0.023 \mathrm{~cd}$ \\
\hline SE & 0.002 & 0.002 & 0.002 & 0.001 \\
\hline $\mathrm{CV}(\%)$ & 7.60 & 6.06 & 8.16 & 6.15 \\
\hline
\end{tabular}

In a column, means having similar letter(s) are statistically similar and those having dissimilar letter(s) differ significantly as per 0.05 level of significance. $\mathrm{CV}=\mathrm{Co}$-efficient of variance. 


\section{References}

Ahmed, M. and Hossain, S. M. A. 1992. Effect of seed rate, nitrogen ferilization and time of harvest on the seed yield of wheat. Bangladesh Agron. J., 4 (1\&2):35-34.

BARI (Bangladesh Agricultural Research Institute). 2006. Wheat production technology (A booklet in Bengali), Wheat Res. Centre, Bangladesh Agril. Res. Inst. Nashipur, Dinajpur. pp. 18-19.

Baron, R.; Benitez, I. C. and Gonzalez, J. L. 1995. The influence of organic matter additions in wheat cultivation. Agronchimica., 39(5):280290.

BBS (Bangladesh Bureau of Statistics). 2010. Statistical Pocket Book of Bangladesh. Bangladesh Bureau of Statitics Division, Ministry of Planning. Goventment People's Republic of Bangladesh. pp. 194.

Davarynejad, G. H.; Haghnia, G. H. and Lakzian, A. 2004. Effect of municipal compost in combination with chemical fertilizers and manure on growth and yield of wheat. Agril. Sci. Tech., 18(1): 101-108.

FAO (Food and Agricultural Organization). 2010. Production Year Book. FAO. UN. Italy. Rome. p. 95-98.
FAO (Food and Agriculture Organization). 2000. Production Yearbook. Food and Agriculture Organization of the United Nations, Rome, Italy. p. 62.

Gomez, K. A. and Gomez, A. A. 1984. Statistical Procedures for Agricultural Research. $2^{\text {nd }}$ Edn. John Wiley and Sons. New York. Chichester, Brisbane, Toronto, Singapore. p. 680.

Hunt, R. 1978. Plant growth analysis. Studies in Biology. No. 96. Edward Arnold L., Londen, $67 \mathrm{P}$.

Razzaque, M. A.; Sufian, M. A. and Badaruddin, M. 1992. Wheat in the national economy of Bangladesh. Proc. Adv. Crop. Sci. Biennial Conf. Crop Sci., Bangladesh. BAU, Mymensingh, 13-25.

Singh, C. P. J. and Singh, S. S. 2000. Studies on the growth and yield parameters of wheat (Triticum aestivum L.) to urea and sludge based compost application. Madras Agril. J., 87(10-12):727-728. 